He attempted unsuccessfully to go to Switzerland before the outbreak of the War. His present whereabouts are uncertain. Ries, Wettstein and probably Seidel are dead. K. Henke and E. v. Holst (Göttingen), Paula Hertwig (Berlin), Hans Nachtsheim and Otto Warburg (Berlin-Dahlem) appear to have been alive at the end of the War, but no news of them has since been received. J. Haemmerling moved from Berlin-Dahlem to the Institut für Seenforschung on the Lake of Constance, but nothing has recently been heard from him.

(4) Hungary and Czechoslovakia. I have just heard through the Red Cross that Dr. Alexander Wolsky, the zoologist at the Biological Research Station at Tihany, is alive and well (and also his family) and that the Research Station is undamaged.

I have also heard that Prof. Jan Belehradek, onetime professor of zoology and later rector of the Karlovy University of Prague, is well, though he was imprisoned in a concentration camp for a considerable period.

Those who knew Dr. Wolsky and Prof. Belehradek when they were doing research in London in the '30's will be especially glad to hear this good news of them.

\section{RESEARCH IN THE U.S.S.R. ON THE PHYSIOLOGY OF VISION}

THE physiology of vision has always held a peculiar fascination for the physiological theorist, but recently the urgency of immediate practical problems, brought to a focus by the War, has led to a renewed and more direct approach both in this country and abroad. Recent Russian work in this field is published in Problemy Physiologitchesky Optiky, 2 (Moscow, 1944), which contains sixteen papers from eleven different laboratories. The papers are in Russian, but a generous English abstract of each is given.

Dealing first with work of immediate practical application, V. G. Samsonova has studied the infiuence of size of image, central brightness, ratio of central to peripheral brightness on the visual discrimination time, and has constructed nomograms from which optimum conditions of lighting for factories, etc., can be computed. O. P. Kholmskaya has measured the visibility of traffic lights against a black screen of varying size. The minimum size of screen for optimum visibility is one which subtends an angle of $12^{\prime}$; when the subtended angle is less than $3^{\prime}$ visibility is worse than with no screen at all. C. I. Krol finds that with several stimuli in the visual field and the total area of stimulation kept constant, the sensitivity of the eye varies inversely as the number of stimuli. S. V. Kravkov records changes in visual acuity resulting from auditory stimulation, and $\mathrm{O}$. A. Dobriakova finds that various extraneous stimuli increase the critical frequency for flicker at the red end of the spectrum and decrease it at the blue end ; there is a peak of increase in the orange-red and of decrease in the blue-green and an intermediate neutral zone in the yellow.

Turning to more fundamental researches, N. I. Pinegin has made a detailed quantitative study of the absolute sensitivity of the eye in the ultra-violet; at $365 \mu$ the eye is 11,000 times less sensitive than at $546 \mu$, and the lower limit of vision is $302 \mu$ (Goodeve, Lythgoe and Schneider recently placed the lower limit at $309 \mu)$. Evidence is provided that the effects were due to direct retinal stimulation at this wavelength and were not the result of fluorescence in the eye media. M. N. Livanov has studied action potentials in the visual cortex and lateral geniculate body with the electroencephalograph. P. I. Spielberg has recorded action currents from the human eye by means of special electrodes applied to the eyeball; the method is fairly simple and may prove useful in ophthalmic practice. A. I. Bogoslovsky has investigated the response of the human eye to electrical excitation. Bogoslovsky has also found that in dark adaptation, while the excitability of the retina increases, that of the visual cortex decreases and the two seem to be reciprocally related.

When a coloured object is viewed at increasing distances, a point is reached (when the subtended angle is $10-20^{\prime}$ ) at which the colour changes in a characteristic fashion. B. N. Kompaneisky has studied these colour changes and concludes that the results can best be interpreted on a classical trichromatic theory of colour vision. The method also provides a sensitive test of colour vision; there are some variations even among normal individuals, and colour defectives are readily identified.

\section{FORTHCOMING EVENTS}

(Meeting marked with an asterisk * is open to the public) THE DISCOVERY OF X-RAYS

50Th ANNIVERSARY COMmemoration Programm Medical Meeting

Saturday, November 10

At the Institution of Electrical Engineers, at 2 p.m.

Saturday, November 10 Scientific Meeting

At the Royal Institution, at 10 a.m.

Saturday, November 10 Historical Reviews

At the Institution of Electrical Engineers, at 3.30 p.m.

\section{Saturday, November 10}

Brochemical SocIETY (at the London School of Hygiene, Keppe Street, London, W.C.1), at 11.30 a.m.-Discussion on "The Chemica Basis of Cell Structure and Function" (to be opened by Dr. J. F. Danielli and others).

IRON AND STEEL INSTITUTE (joint meeting with the ScotTISH BRANCH OF THE INSTITUTE OF BRITISH FOUNDRYMEN) (at the Royal Technical College, George Street, Glasgow), at 3 p.m.-Mr. Basil Gray: "The German Steel Foundry Industry".

Monday, November 12

ROYAL GEOGRAPHICAI SOCIETX (at Kensington Gore, South Kensington, London, S.W.7), at 5.30 p.m.-Prof. H. W. Ahlmann : "Summary of Glaciological Researches, 1918-1940".

Tuesday, November 13

Chadwrok PUblic Leoture (at the Royal Sanitary Institute, 90 Buckingham Palace Road, London, S.W.1), at 2.30 p.m.-Mr. F. C. Vokes: "The Modern System of Sewage Disposal and the Methods and Materials Employed" (Bossom Gift Lecture)*.

ROYAI INSTITUTION (at 21 Albemarle Street, London, W.1), at 5.15 p.m.-Dr. A. Müller: "50th Anniversary of the Discovery of X-Rays", (ii) "After the Discovery of X-Rays".

ROYAI SOCIETY OF MEDICINE (at 1 Wimpole Street, London, W.1), at 5.30 p.m.-Discussion on "Forward Psychiatry in the Army" (to be opened by Lieut.-Colonel H. A. Palmer, Ma jor C.

British Association of Chemists, Northern SECtron (in the Chemistry Lecture Theatre, King's College, Newcastle-upon-Tyne) at 7 p.m.-Mr. R. Booth: "The Development and Properties of Safety Glass".

\section{Wednesday, November 14}

ROYal SOcIeTY of ARTS (at John Adam Street, Adelphi, London, W.C.2), at 1.45 p.m.-Mr. A. O. Hartley: "Operation PLUTO".

Institute of PeTrosedm (at 26 Portland Place, London, W.1), at 5.30 p.m.-Flight-Lieut. E. Mikolajewski: "Investigation of Piston Ring Sticking in High Duty Aero Engines".

INSTITUTION OF ELECTRICAL ENGINEERS, TRANSMISSION SECTION (at Savoy Place, Victoria Embankment, London, W.C.2), at $5.30 \mathrm{p.m}$. Voltage Overhead Lines of the British Grid System".

BRITISH INSTITUTION OF RADIO ENGINEERS (at the Neville Hall, BRITISH INSTITUTION OF RADIO ENGINEERS (at the Neville Hall,
Westgate Road, Newcastle-upon-Tyne), at 6 p.m.-Mr. S. G. Button: “U.H.F. Aerial'Systems". 